\title{
Study of efficacy and safety of bipolar coagulation in total laparoscopic hysterectomy
}

\author{
Shrirame DV', Malkar $\mathbf{V}^{2}$, Modi $\mathbf{R}^{3}$ \\ ${ }^{1}$ Dr. Deepti V. Shrirame, Trainee for IAGE fellowship in Gynaecological Endoscopy, ${ }^{2}$ Dr. Vilas Malkar \\ Lecturer, PSM Akola Medical College, Akola, Maharashtra, India, ${ }^{3}$ Dr. Rajesh Modi, Director, Akola \\ Endoscopy Centre, Akola, Maharashtra, India.
}

Address for Correspondence: Dr. Rajesh Modi (Director, Akola Endoscopy Centre). E-mail id: vilasmalkar@yahoo.com

\begin{abstract}
Aim: To study the efficacy and safety of bipolar coagulation in total laparoscopic hysterectomy. Methods: A single surgeon, single center, retrospective study of one year was conducted in Akola Endoscopy center from 1 May 2010 to $30^{\text {th }}$ April,2011. 200 patients who underwent total laparoscopic hysterectomy for benign conditions were enrolled. Data about the surgical time, estimated blood loss, related complications and length of hospital stay were evaluated. Results: The patients who underwent TLH with bipolar coagulation in the present study, it was found that the mean operating time was $52.83+-12.28 \mathrm{~min}$, mean blood loss was $40.50+-28.02 \mathrm{ml}$, postoperatively febrile morbidity was found to be in $1.5 \%$ of patients and secondary hemorrhage in $2.5 \%$ with average hospital stay around 9-10 hours. No patient required blood transfusion or re-laparotomy. There were no intra-operative or anesthetic complications and no case of hernia or mortality. Conclusion: bipolar coagulation for hemostasis used in laparoscopic hysterectomy is safe and effective.
\end{abstract}

Keywords: Total laparoscopic hysterectomy,bipolar coagulation,hemostasis

\section{Introduction}

Hemostasis is the most important aspect of any surgical procedure. This is especially true in the performance of laparoscopic surgery where because of visual, tactile and mechanical limitations; prevention of bleeding is preferable to searching for bleeding vessels. Methods of hemostasis include endoscopic suturing techniques, staples, clips, lasers, mono-polar and bipolar coagulation, vessel sealing devices, plasma kinetic devices and ultra-Sonics. Of these bipolar coagulation is a simple economical energy source. It heralds an age of improved hemostasis. It is an indispensable part of the laparoscopic surgeon's armamentarium. Bipolar coagulation was first documented by Dr. Harvey. W. Cushing with the assistance of Dr. William T. Bovie of Harvard University in 1926, where he completed his first removal of brain tumor using electrocautery. He described the principles in depth regarding both the art as well as

Manuscript received: $25^{\text {th }}$ June 2017

Reviewed: $5^{\text {th }}$ July 2017

Author Corrected: $14^{\text {th }}$ July 2017

Accepted for Publication: $21^{\text {st }}$ July 2017 biophysics of electro -Surgery. In 1989, Dr. Harry Reich described first laparoscopic hysterectomy using bipolar desiccation [1,2,3,4,5]. Vidarbha and adjoining Madhya-Pradesh, Chattisgarh and Telangana States have majority of the people in low socio-economic status and it is really difficult for these people to go to metro cities for lap operations and bear high cost. Each one of us desires to get the best medical treatment available.

This study gives us an insight that bipolar coagulation is equally safe, effective, feasible and in-expensive method of hemostasis in TLH and thus not depriving the patients from best medical facilities only for the want of money.

The aim to publish in scientific journal is to spread the technique with respect to its economic viability and safety in every nook and corner of the world and also enable the doctors to practice in areas of economical constraint. The study will also help to improve the image of India as Medical Hub. 


\section{Material and Methods}

A single surgeon, single center retrospective study was conducted in Akola Endoscopy center (Akola, Maharashtra, India) from 1 May 2010 to 30 April, 2011. Inclusion criteria: 200 patients with DUB and fibroid who underwent total laparoscopic hysterectomy for benign conditions were enrolled. Data about the operation time, estimated blood loss, related complications and length of hospital stay were evaluated. Exclusion criteria: for total laparoscopic hysterectomy included malignancy and prolapse.

Surgical Technique: A $10 \mathrm{~mm} 30$ degree laparoscope is used through the supra-umbilical port followed by 3 ancillary $5 \mathrm{~mm}$ ports (two on surgeon's side and one on assistant side). After visualizing the whole abdominal cavity a steep head low is given so that the small bowel loops fall towards the diaphragm. The uterus is pulled up with the help of a $5 \mathrm{~mm}$ laparoscopic myoma screw introduced at the fundus near the cornual end for traction. The bipolar graspers [6] and scissors are used to coagulate and cut the left tube, round ligament, ovarian ligament and mesosalpingeal vessels, uterosacrals respectively. Cutting the uterosacrals allow the peritoneum of lateral pelvic wall to fall back by almost $2-3 \mathrm{~cm}$ helping the ureter to be pulled away from the surgical field. Anteriorly the UV fold is lifted, coagulated by bipolar and cut and bladder pushed back over the cervix. The bladder pillar fibers are coagulated and pushed back, exposing the uterine artery completely. After skeletonisation of uterine vessels, a segment of uterine is coagulated and cut at the level of isthmus. The same steps are repeated on the right side. The rest of the vagina is cut circumferentially using bipolar coagulation and scissors. Uterus is removed vaginally or if $>12$ weeks size, morcellated and removed. Vault closure is done with vicryl no 2-0 or vicryl rapid no $2-0$ with 2 figure of 8 stitches. Saline $700-800 \mathrm{ml}$ is left in the peritoneal cavity.

Concerns regarding bipolar like1) collateral damage 2) charring 3) sticking of tissue to bipolar, were prevented by following measures.

1) Low voltage setting at 16 allowing slow cooking of the tissues.

2) Intermittent coagulation so that bipolar is removed when the tissue is already wet preventing sticking to bipolar.

Patients were discharged on the same day after 910 hours.

\section{Results}

In our study, the patients had a mean age of $43.05+-06.15$ with mean parity $2.135+-0.71$. The mean operating time was 52.83+-12.28 min, mean blood loss 40.50+-28.02 ml. Blood loss and operating time were significantly more in case of previous surgery and adhesions. There were no intraoperative complications and the average hospital stay was 9-10 hours. Post operatively $22.5 \%$ patients had mild febrile response (due to inflammation of the tissues).

Table-1: Depicting blood loss, duration of surgery, type of adhesion.

\begin{tabular}{|c|c|c|c|c|c|}
\hline Blood loss & $<20 \mathrm{ml}$ & $20-50 \mathrm{ml}$ & $50-100 \mathrm{ml}$ & $>100 \mathrm{ml}$ & Total \\
\hline No & 62 & 95 & 34 & 9 & 200 \\
\hline$\%$ & 31 & 47.5 & 17 & 4.5 & 100 \\
\hline $\begin{array}{c}\text { Duration of } \\
\text { surgery }\end{array}$ & $<45 \mathrm{~min}$ & $45-60 \mathrm{~min}$ & $60-90 \mathrm{~min}$ & $>90 \mathrm{~min}$ & Total \\
\hline No & 41 & 87 & 61 & 10 & 200 \\
\hline$\%$ & 20.5 & 43.5 & 30.5 & 5 & 100 \\
\hline $\begin{array}{c}\text { Type of } \\
\text { adhesion }\end{array}$ & Nil & Flimsy & Bowel & Omentum & Total \\
\hline No & 114 & 10 & 10 & 66 & 200 \\
\hline$\%$ & 57 & 5 & 5 & 33 & 100 \\
\hline
\end{tabular}

This table shows that $47.5 \%$ patients had blood loss between 20 to $50 \mathrm{ml}$, in $43.5 \%$ cases the duration of surgery was $45-60 \mathrm{~min}$, in $57 \%$ case there were no adhesions. 
Table-2: depicting mean, SD and Range for age, parity, blood loss and duration of surgery.

\begin{tabular}{|c|c|c|c|}
\hline & Mean & SD & Range \\
\hline Age & 43.05 & 6.15 & $27-66$ \\
\hline Parity & 2.135 & 0.71 & \\
\hline Blood loss & 40.5 & 28.02 & \\
\hline Duration of surgery & 52.83 & 12.28 & \\
\hline
\end{tabular}

This table shows that mean age was 43.05 years, mean parity 2.135 , mean blood loss $40.5 \mathrm{ml}$ and mean duration of surgery was $52.83 \mathrm{~min}$.

Table-3: depicting No of Patients as per Diagnosis, Adhesions, Ovarian pathology, previous surgery.

\begin{tabular}{|c|c|c|c|}
\hline Diagnosis & DUB & Fibroid & Total \\
\hline No & 111 & 89 & 100 \\
\hline$\%$ & 55.5 & 44.5 & Total \\
\hline Adhesions & present & 86 & 100 \\
\hline No & 114 & 43 & Total \\
\hline$\%$ & 57 & Absent & 200 \\
\hline Ovarian pathology & present & 162 & 100 \\
\hline No & 38 & 81 & Total \\
\hline Previous surgery & 19 & Absent & 200 \\
\hline No & present & 155 & 100 \\
\hline
\end{tabular}

This table shows that $55.5 \%$ case were of DUB, in $57 \%$ cases adhesions were present, ovarian pathology was present in $19 \%$ cases and $22.5 \%$ cases had history of previous surgery.

Table-4: Comparison with other studies as per Blood loss (ml).

\begin{tabular}{|c|c|c|c|c|}
\hline & Mean & SD & Total & Test of significance \\
\hline Present study & $40.5 \mathrm{ml}$ & 28.02 & 200 & $\begin{array}{c}\mathrm{SE}=17.0 \\
2 \mathrm{z}=10.84 \\
\mathrm{P}<0.05\end{array}$ \\
\hline Chausa study [7] & $225 \mathrm{ml}$ & 195 & 133 & \\
\hline $\mathrm{FD}(\mathrm{EBVS})[8]$ & 87.76 & 25.48 & 21 & $\begin{array}{l}\mathrm{SE}=5.9 \\
\mathrm{z}=8.00 \\
\mathrm{p}<0.05\end{array}$ \\
\hline Chausa study (PK) & 140 & 45.9 & 10 & $\begin{array}{c}\mathrm{SE}=14.6 \\
5 \mathrm{z}=6.80 \\
\mathrm{P}<0.05\end{array}$ \\
\hline Katherine A et al [9] & 130 & 189 & 830 & $\begin{array}{c}\mathrm{SE}=6.85 \\
\mathrm{Z}=13.06 \\
\mathrm{P}<0.05\end{array}$ \\
\hline FD(Ultrasonic) & 152.63 & 60.9 & 19 & $\begin{array}{c}\mathrm{SE}=14.1 \\
\mathrm{z}=7.95 \\
\mathrm{p}<0.05\end{array}$ \\
\hline
\end{tabular}

As compared to other studies including Chausa ,Katherine studies, our study using bipolar shows less blood loss i.e, around $40.5 \mathrm{ml}$. 
Table-5: Comparison with other studies as per Surgical Time (minutes).

\begin{tabular}{|c|c|c|c|c|}
\hline & Mean & SD & Total & Test of significance \\
\hline Present study & 52.83 & 12.28 & 200 & $\begin{array}{c}\mathrm{SE}=3.66 \\
\mathrm{Z}=4.31 \\
\mathrm{P}<0.05\end{array}$ \\
\hline Chausa study[7] & 68.6 & 15.9 & 20 & \\
\hline $\mathrm{FD}(\mathrm{EBVS})[8]$ & 59.57 & 3.71 & 21 & $\begin{array}{c}\mathrm{SE}=1.19 \\
\mathrm{Z}=5.68 \\
\mathrm{P}<0.05\end{array}$ \\
\hline $\begin{array}{l}\text { Chausa study } \\
\qquad(\mathrm{PK})[8]\end{array}$ & 69.2 & 15.9 & 10 & $\begin{array}{c}\mathrm{SE}=5.1 \\
\mathrm{z}=3.2 \\
\mathrm{p}<0.05\end{array}$ \\
\hline $\begin{array}{c}\text { Katherine A .et al } \\
\text { [9] }\end{array}$ & 132 & 55 & 830 & $\begin{array}{l}\mathrm{SE}=2.1 \\
\mathrm{z}=37.7 \\
\mathrm{p}<0.05\end{array}$ \\
\hline FD(Ultrasonic) & 90.95 & 5.73 & 19 & $\begin{array}{c}\mathrm{SE}=1.58 \\
\mathrm{z}=24.20 \\
\mathrm{P}<0.05\end{array}$ \\
\hline
\end{tabular}

Surgical time for laparoscopic hysterectomy using bipolar in our study was 52.83 minutes which was less as compared to other studies.

Table-6: Depicting relation between surgical time in minutes and previous surgery and adhesions.

\begin{tabular}{|c|c|c|c|c|c|}
\hline & & Mean & SD & No & Test of significance \\
\hline $\begin{array}{c}\text { Previous } \\
\text { surgery }\end{array}$ & Present & 60.23 & 12.81 & 43 & $\begin{array}{c}\text { SE }=2.15 \\
\mathrm{z}=4.48 \\
\mathrm{p}<0.05\end{array}$ \\
\hline & Absent & 50.61 & 11.25 & 157 & $\begin{array}{c}\mathrm{SE}=1.72 \\
\mathrm{Z}=4.31 \\
\mathrm{p}<0.05\end{array}$ \\
\hline Adhesion & Present & 57.04 & 12.79 & 86 & \\
\hline
\end{tabular}

This table shows that surgical time is increased if there is history of previous surgery and presence of adhesions.

Table-7: Depicting relation between Blood Loss and previous surgery and adhesions.

\begin{tabular}{|c|c|c|c|c|c|}
\hline & & Mean & SD & No & Test of significance \\
\hline $\begin{array}{c}\text { Previous } \\
\text { surgery }\end{array}$ & Present & 46.08 & 31.95 & 43 & $\begin{array}{c}\text { SE }=5.32 \\
\mathrm{z}=1.97 \\
\mathrm{p}<0.05\end{array}$ \\
\hline & Absent & 38.83 & 26.63 & 157 & $\mathrm{SE}=4.08$ \\
$\mathrm{z}=2.20$ \\
\end{tabular}

We can conclude from this table that blood loss is increased if there is history of previous surgery and presence of adhesions. 
Table-8: depicting relation between Adhesions and previous surgery.

\begin{tabular}{|c|c|c|c|}
\hline \multirow{2}{*}{ Previous surgery } & \multicolumn{2}{|c|}{ Adhesions } & Total \\
\cline { 2 - 4 } & Present & 1 & 45 \\
\hline Present & 44 & 113 & 155 \\
\hline Absent & 42 & 114 & 200 \\
\hline Total & 86 & $\mathrm{df}=1$ & $\mathrm{p}<0.05$ \\
\hline
\end{tabular}

In this table 86 patients had adhesions of which 44 patients had history of previous surgery

\section{Discussion}

Hospital stay in Katherine et al[9] study was 1.4 days, Thailand [10] study was 3 days both with ultrasonic use. In our study, blood loss, hospital stay, and surgical time were comparatively less when compared to other studies. Intraoperative complications were nil including conversion to open cases or collateral damage. We had no incisional hernia following TLH due to use of 5 $\mathrm{mm}$ ports. Hernia in other studies was due to the use of larger ports [11]. Use of $5 \mathrm{~mm}$ trocars in our study not only avoided risk of incisional hernia but also those specific to the use of endoscopic linear staplers [12]. Also bipolar coagulation is perfectly reliable for hemostasis even for large vessels like uterine artery and ovarian artery. There was no post-operative hemorrhagic complication requiring further operations and blood transfusions. Therefore bipolar can be efficiently used as it is simple, inexpensive and re-usable with efficient hemostasis in all situations required by TLH [13].

We all are aware that vaginal hysterectomy is safe, fast, minimally invasive and cost effective. Abdominal hysterectomy is decreasing except being used for malignancy and very large uterus. If lap hysterectomy is carried out with exclusively reusable equipment like bipolar and trocars, the hospital cost is similar to vaginal route or laparotomy.

Therefore lap surgery can be used as an alternative to vaginal or and laparotomy for hysterectomy in this fast world where less tissue handling and fewer opportunities for foreign body contamination such as lint and suture, decreased post-operative adhesion formation, improved cosmetic results, reduced post-operative discomfort and short hospital stay and convalescence period are highly desirable leading to quick return to normal life and thus significantly reducing the cost of operation
$[14,15,16,17,18,19,20,21,22]$. Therefore this data suggests that bipolar is very effective and safe for TLH, if the surgeon is skilled and experienced. Once you master the operating skill of bipolar coagulation, it is a simple, economical energy equipment.

\section{Conclusion}

Bipolar electro-surgery has been proved to be an effective, safe and economical tool in the hands of skilled and expert surgeon in total laparoscopic hysterectomy.

\section{Funding: Nil, Conflict of interest: None Permission of IRB: Yes}

\section{References}

1. Ketan R Bulsara, Sunny Sukhla, Shahid M Nimjee. History of bipolar coagulation. Neurosurgery Rev 2006;29;93-96.

2. Reich H., DeCaprio J and McGlynn F. Laparoscopic hysterectomy J.Gynecol.Surg, 1989; 5, 213-216.

3. Vidyashree Ganesh Poojari. Total Laparoscopic Hysterectomy with Prior Uterine Artery Ligation at its Origin [Internet]. Lauren A. Wise; 2014 November 19. Available from: https://www. hindawi. com/journals/ijrmed/2014/420926/

4. David McClusky. Principles of Laparoscopic Hemostasis[Internet].Available from:https:// www. sages. org/wiki/principles-laparoscopic-hemostasis/

5. Prakash Trivedi et al. Do New Vessel Sealing Devices and Harmonic Ace Increase Ureteric Injury in Total Laparoscopic Hysterectomy? J Gynecol Endosc Surg. 2009 Jul-Dec; 1 (2): 83-88. doi: 10.4103/0974-1216.71613. 
6. Nutan Jain. State of Art Atlas of Endoscopic Surgery in Infertility and Gynaecology. $2^{\text {nd }}$ Edition. Laparoscopic cutting and haemostasispg 34-37.

7. ChauSu OU, James Joki.et al. Total laparoscopic hysterectomy using Multifunction Grasping coagulating, and cutting forceps. Journal of Laparoendoscopic \& Advanced Surgical Techniques. 2004;14(2):67-71.

8. Demirtuk F, Aytan H, Caliskan AC. Comparison of the use of electro-thermal bipolar vessel sealer with harmonic scalpel in total laparoscopic hysterectomy. J Obstet Gynaecol Research 2007 June, 33 (3):341-5.

9. Katherine A.O Hanlan, Suzannel Dibble, AnneCaroline arnier Bs, Mirjam Leuchlenberger Reuland. Total Laparoscopic Hysterectomy: Technique and Complications of 830 Cases JSLS. 2007 Jan-Mar; 11(1): 45-53.

10. Srisombut C, Weerakiet S. Laparoscopic Hysterectomy using laparo-sonic coagulating shears experience of 15 cases. J Med Assoc Thai. 200 Aug;83(8):915-20.

11. Kadar N, Reich,H., Liu,C.Y.et al. Incisional hernia after major laparoscopic gynecologic procedures Am. J Obstet Gynecol. 1993;168 (5): 1493-1495

12. Nezhat C., Nezhat F, Bess $\mathrm{O}$ et al. Injuries associated with the use of a linear stapler during operative laparoscopy. review of diagnosis, management and prevention. J Gynecol.Surg, 1993; 9: $145-150$.

13. Chapron C, Dubuisson JB, Aubert V. Laparoscopic hysterectomy: it is not such an expensive surgical procedure. Am J Obstet Gynecol. 1994 Apr;170(4):1210-1.
14. Loh FH, Canis M, Ng SC. Laparoscopic hysterectomy--a step forward? Singapore Med J. 1995 Apr; 36(2):197-203.

15. Matthews B, Nalysnyk L, Estok R, Fahrbach K, Banel D, Linz H, Landman J. Ultrasonic and nonultrasonic instrumentation: a systematic review and meta-analysis. Arch Surg. 2008 Jun;143 (6): 592-600. doi: 10.1001/archsurg.143.6.592.

16. Jan Fickling, Cherie Ryan Loeffler RN. Basics of Bipolar Surgery. Hotline News Volume 4 Issue 4 Dec;1999.

17. Parker WH. Total laparoscopic hysterectomy. Obstet Gynecol Clin North Am. 2000 Jun; 27 (2): 431-40.

18. Harris WJ. Complications of hysterectomy. Clin Obstet Gynecol. 1997 Dec;40(4):928-38.

19. Wu MP, Ou CS, Chen SL, Yen EY, Rowbotham R. Complications and recommended practices for electrosurgery in laparoscopy. Am J Surg. 2000 Jan;179(1):67-73.

20. Pakarian F, Spencer C A series of laparoscopic hysterectomies for benign diseases: a single center single surgeon prospective study of complications confirming previous retrospective study BJOG 2010; 117:752-755.

21. Leung PL, Tsang SW, Yuen PM. Quality Assurance Subcommittee in Obstetrics and Gynaecology, Hospital Authority, Hong Kong. An audit on hysterectomy for benign diseases in public hospitals in Hong Kong. Hong Kong Med J. 2007 Jun;13(3):187-93.

22. S Mehra, R Bokaria, A Gujral, V Bhat, M Hotchandani. Experience in laparoscopic hysterectomy: analysis of 300 cases. Annals of the Academy of Medicine, Singapore 1996; 25(5): 660-4.

\section{How to cite this article?}

Shrirame DV, Malkar V, Modi R. Study of efficacy and safety of bipolar coagulation in total laparoscopic hysterectomy. Int J Med Res Rev 2017;5(07):748-753.doi:10.17511/ijmrr. 2017.i07.14. 